岩手県内の農場で死亡した牛における牛ウイルス性

下痢ウイルスの感染状況調査

\author{
福成和博 ${ }^{1 \dagger}$ 八重樫岳司 ${ }^{1)}$ 千葉 伸 $^{1)}$ 亀山健一郎 ${ }^{2)}$
}

1）岩手県中央家畜保健衛生所（ $\bar{T} 020-0173$ 岩手郡滝沢村滝沢字砂达 390-5）

2）独農業・食品産業技術総合研究機構＼cjkstart動物衛生研究所（† 305-0856 つくば市観音台 3-1-5)

( 2013 年 5 月 2 日受付 $\cdot 2013$ 年 8 月 27 日受理)

要 約

2011 年 3 月 2013 年 3 月までの 25 カ月間に岩手県内の 2,203 農場で死亡し，牛海綿状脳症（BSE）検査に用いられ た 2 歳齢以上の 9,362 頭の牛の延䯣を活用し，牛ウイルス性下痢ウイルス（BVDV）感染状況を調查したＢVDVは飼 養農場 31 戸 $(1.41 \%)$ の 36 頭（0.38\%）から検出され，年齢別では死亡時に 2 歳齢であった牛が $1.72 \%$ (22 頭/ 1,279 頭)，生産農場の経営形態別では酪農場が $1.76 \%$ (25戸/1,417戸) と有意に高い検出率を示した。また，36 分離 株に㧍りる 2 型BVDVの割合も $22.2 \%$ と高く，過去に行われた県内調查の結果と異なっていた．これらの成績から，本 県に扔けるBVD の清浄化には，酪農場におけるBVDVの監視及び2 型ウイルスの対策が重要であることが示唆された。 死亡牛を活用したBVDV 検查はBVDVの感染状況及び疫学調查に利用可能であると考えられた。

—キーワード：牛ウイルス性下㾥ウイルス (BVDV), 死亡牛, 疫学, 遺伝子型, 延䯣.

日獣会誌 $66,785 \sim 790(2013)$

牛ウイルス性下㾥ウイルス (BVDV) 非細胞病原性 (NCP) 株の妊娠初期の牛への感染は, 垂直感染の結果, 同ウイルス持続感染（PI）牛の分婏を引き起こす $[1$, 2]. PI 牛は生涯にわたり多量のウイルスを排出し, 他の 牛への感染源となり $[1,3,4]$, 多くは発育不良や虚弱 などにより 2 歳齢までに淘汰されるか粘膜病を発症し死 亡する $[1,4-7]$. それ以降も生存し飼養され続けた場 合には, 本牛自身が発育遅延等を示すほか, 急性感染症 による他牛の生産性低下に影響を与える要因となるため $[1,3-5,8], \mathrm{PI}$ 牛の早期把握及び牛群からの早期排除が 本病の対策上重要である。本県では, 1975 年以降, 年 間数例の発育不良又は粘膜病など臨床症状を示した牛が BVDV 感染症と診断されているが, 臨床的な異常を示す ことなく飼養されている PI 牛の浸潤状況に関する調査 は行われていない.

2002 年度から全国で牛海綿状脳症（BSE）特別措置 法に基づく BSE 検査が，死亡した 2 歳齢以上の牛を対 象として行われている。およそ 15 万頭の牛が飼養され
ている本県では，年間約 3,500 頭の成牛が同検査の対象 となり，材料としてそれらの延髄が採取されている．同 材料が BVDV 検査に活用できれば，県内広域のBVDV の動態を監視する有用な手法となり得る.

この報告では，発育不良及び虚弱などの所見を示すこ となく生育し，粘膜病を発症せずに飼養され続けたPI 牛を把握し，その実態を明らかにすることを目的に，県 内死亡牛の BSE 検査材料を活用した BVDV 感染状況調 査の成績を述べる.

\section{材料及び方法}

検査材料： 2011 年 3 月〜 2013 年 3 月までの 25 力月 間に岩手県内で死亡した牛のうち，BSE 検査に供され た 2 歳齢以上の牛 9,362 頭の延髄を材料とした．飼養農 場の内訳は，県内全 33 市町村の酪農場 1,090戸 7,200 頭，肉用牛繁殖農場 1,092 戸 1,793 頭，肥育農場 145 戸 369 頭であった，各農場区分に重複があるため，飼養農 場の実戸数は 2,203 戸であった。生産農場の内訳は, 県

$\dagger$ 連絡責任者：福成和博（岩手県中央家畜保健衛生所） 干 020-0173 岩手郡滝沢村滝沢字砂込 390-5

8019-688-4111 FAX 019-688-4012

E-mail : k-fukunari@pref.iwate.jp 
農場死亡牛の牛ウイルス性下痢ウイルス感染状況調查

表 $1 \quad$ BVDV 陽性牛の疫学情報

\begin{tabular}{|c|c|c|c|c|c|c|c|}
\hline \multicolumn{3}{|c|}{ 生産農場 } & \multicolumn{4}{|c|}{ 飼養農場 } & \multirow[b]{2}{*}{ 陽性牛の農場間移動パターン } \\
\hline 経営形態 & 農場数 & $\begin{array}{c}\text { 母牛 } \\
\text { 用途 (品種) }\end{array}$ & 経営形態 & 農場数 & $\begin{array}{c}\text { 陽性牛* } \\
\text { 用途 (品種) }\end{array}$ & $\begin{array}{c}\text { 陽性頭数 } \\
\text { (内導入頭数) }\end{array}$ & \\
\hline \multirow{2}{*}{ 酪農 } & \multirow{2}{*}{25} & \multirow{2}{*}{ 搾乳（Hol） } & 酪農 & 19 & 搾乳（Hol） & $21 \quad(9)$ & 酪農場＜wide>酪農場 \\
\hline & & & 肥育 & 6 & 肥育（F1） & $7 \quad(7)$ & 酪農場 $\rightarrow$ 肥育農場 \\
\hline 計 & 25 & & & 25 & & $28(16)$ & \\
\hline \multirow{2}{*}{ 肉用牛繁殖 } & \multirow{2}{*}{8} & \multirow{2}{*}{ 繁殖（JB） } & 肉用牛繁殖 & 2 & 繁殖（JB） & $2 \quad(2)$ & 肉用牛繁殖農場 $\rightarrow$ 肉用牛繁殖農場 \\
\hline & & & 肥育 & 4 & 肥育（JB） & $6 \quad(4)$ & 肉用牛繁殖農場 $\rightarrow$ 肥育農場 \\
\hline 計 & 8 & & & 6 & & $8 \quad(6)$ & \\
\hline 合計 & 33 & & & 31 & & $36(22)$ & \\
\hline
\end{tabular}

*Hol：ホルスタイン種, JB : 黒毛和種, $\mathrm{F} 1$ : 交雑種 $(\mathrm{Hol} \times \mathrm{JB})$

表 2 年齢別及び生産農場経営形態別のBVDV 陽性率

\begin{tabular}{|c|c|c|c|c|c|c|c|}
\hline 区 分 & & $\begin{array}{l}\text { 農場数 } \\
\text { (A) }\end{array}$ & $\begin{array}{l}\text { 検査頭数 } \\
\text { (B) }\end{array}$ & $\begin{array}{c}\text { 陽性農場数 } \\
\text { (C) }\end{array}$ & $\begin{array}{l}\text { 陽性頭数 } \\
\text { (D) }\end{array}$ & $\begin{array}{c}\text { 農場 } \\
\text { 陽性率(\%) } \\
(\mathrm{C} / \mathrm{A} \times 100)\end{array}$ & $\begin{array}{c}\text { 頭数 } \\
\text { 陽性率 }(\%) \\
(\mathrm{D} / \mathrm{B} \times 100)\end{array}$ \\
\hline 年齢別 & & & 9,362 & & 36 & & 0.38 \\
\hline \multirow[t]{3}{*}{2 歳齢 } & & & 1,279 & & 22 & & $1.72^{\mathrm{a} *}$ \\
\hline & （肥育） & & 353 & & 13 & & $3.68^{\mathrm{b}}$ \\
\hline & (搾乳・繁殖) & & 926 & & 9 & & $0.97^{\mathrm{c}}$ \\
\hline 3 歳齢以上 & （搾乳・繁殖） & & 8,083 & & 14 & & $0.17^{\mathrm{a}, \mathrm{b}, \mathrm{c}}$ \\
\hline 生産農場経営形態別 & & 2,913 & 9,362 & 33 & 36 & 1.13 & 0.38 \\
\hline 酪農 & & 1,417 & 7,203 & 25 & 28 & $1.76^{\mathrm{d}}$ & 0.39 \\
\hline 肉用牛繁殖 & & 1,337 & 2,000 & 8 & 8 & $0.60^{\mathrm{d}}$ & 0.40 \\
\hline 不明 & & 159 & 159 & 0 & 0 & 0.00 & 0.00 \\
\hline
\end{tabular}

$* \mathrm{a}-\mathrm{d}$ の同符号間に有意差あり $(\mathrm{a}, \mathrm{b}, \mathrm{c}: P<0.001, \mathrm{~d}: P<0.01)$

内を含む 23 道県の酪農場 1,417 戸，肉用牛繁殖農場 1,337 戸, 不明 159 戸であった。これらの牛から採取され た延髄を死亡後 3 〜 15 日以内にBSE 検査の市販キット $\left(\mathrm{TeSeE}^{\mathrm{TM}}\right.$ PURIFICATION KIT，バイオ・ラッドラボ ラトリーズ(株，東京）を用いて乳剤を作製し， - $30{ }^{\circ} \mathrm{C}$ で保存後， 1 週間以内にBVDVの検査に供した.

RT-PCR：延髄乳剂 10 頭分を混合し，市販キット (TRIzol LS Reagent, ライフテクノロジーズジャパン (株，東京）を用いて全RNAを抽出したＢVDV 遺伝子 の検出は，324及び 326 のプライマーペア［9］を用い て 5'末端非翻訳領域（UTR）の 288 塩基を増幅した。 RT-PCRは市販キット（SuperScript One-Step RTPCR with Platinum Taq, ライフテクノロジーズジャパ ン(株)，東京）を使用し， $50{ }^{\circ} \mathrm{C} / 30$ 分， $94{ }^{\circ} \mathrm{C} / 2$ 分の cDNA 合成後, $94{ }^{\circ} \mathrm{C} / 1$ 分, $55{ }^{\circ} \mathrm{C} / 1$ 分, $72{ }^{\circ} \mathrm{C} / 1$ 分 を 1 サイクルとして 40 サイクル繰り返した後に, $72{ }^{\circ} \mathrm{C} / 10$ 分間反応させた。増幅産物の確認はアガロー スゲル電気泳動により行った. BVDV 遺伝子が検出され た場合には，延髄乳剤から同様の方法でRT-PCR を行 い，同遺伝子が検出された個体を特定した。

ウイルス分離：BVDV 遺伝子が検出された死亡牛の
延髄乳剤を材料とし，常法［10］に準じた免疫染色を行 った. 96 穴プレートに 10 倍希釈した乳剤 $100 \mu l$ 及び馬 血清馴化牛胎子筋肉細胞 $100 \mu l$ を同時に接種した。約 1 週間の培養後，上清を除去し，乾燥固定後，1 次抗体 (JCU/BVD/CF10, TropBio, Australia), 2 次抗体 (Blotting Grade Affinity Purified Goat Anti-Mouse IgG $(\mathrm{H}+\mathrm{L})$ Horseradish Peroxidase Conjugate, バ イオ・ラッドラボラトリーズ(株), 東京), 基質溶液の順に 反応させ, 抗原が特異的に染色された検体を陽性とした。

疫学調査及び統計処理：調査対象牛全頭の個体情報 （飼養農場，生産農場，年齢，用途，品種及び移動歴） は，個体識別情報検索サービス（URL：http://www， id.nlbc.go.jp/top.html）から得た。また，BVDV 検出 率を年齢別及び生産農場経営形態別で比較し, Fisher の正確確率検定により統計処理を行い，いずれも危険率 $1 \%$ 未満を統計学的有意差ありと判定した。

5'-UTR の塩基配列決定及び分子系統解析：RT-PCR 増幅産物を市販キット（QIAquick PCR Purification Kit，(株キアゲン，東京）により精製後，市販キット (Big Dye Terminator v1.1 Cycle Sequencing Kit, ラ イフテクノロジーズジャパン(株)，東京）を用いたサイク 


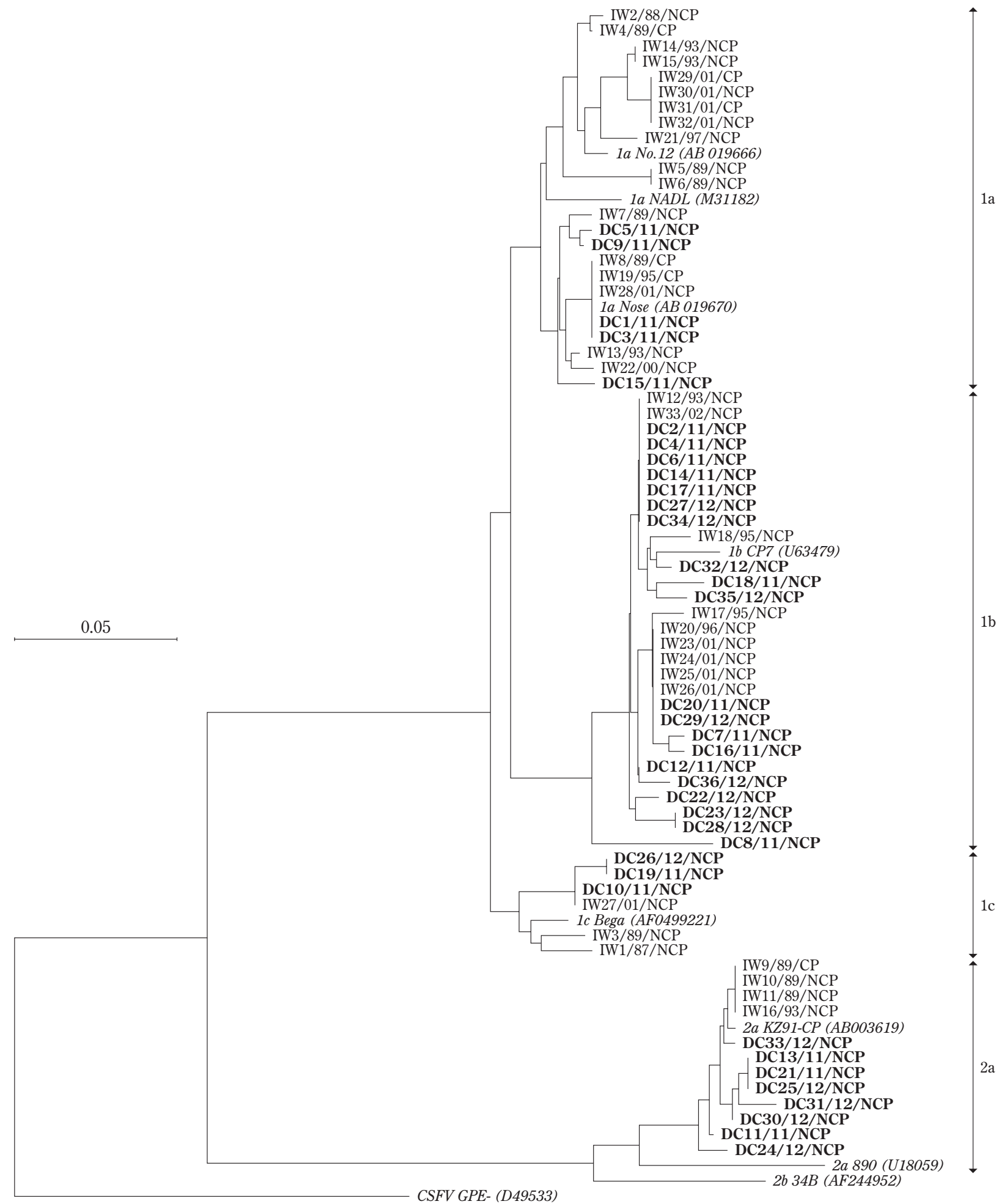

図＼cjkstart県内分離株の分子系統樹

5'-UTR 領域における塩基配列より Neibour-joining 法を用いて分子系統樹を作製した。太字は本研究における分離株，斜 体は遺伝子データベース上の参照株を示す. 各ウイルスの株名は「分離順位/分離年/生物型」とした.

ルシークエンス反応を行った。反応産物は市販キット (BigDye XTerminator Purification Kit, ライフテクノ ロジーズジャパン(株，東京）を用いて余剰標識 dNTPs を除去後，オートシークエンサー (Applied Biosystems 3130x Genetic Analyzer, ライフテクノロジーズ
ジャパン(株)，東京）で分析し，塩基配列を決定した。得 られた約 240 塩基の配列は，フリーソフトの MEGA4 [11］で整列化し，本県で過去に分離された 33 株（IW1 〜 IW33）［12］及びGeneBank データベース上の参照 株とともにNeighbor-joining 法［13］により分子系統 
樹を作成し，遺伝子型を決定した.

\section{成績}

BVDV の検出状況：BVDV遺伝子は飼養農場 31 戸 $(1.41 \%)$ の 36 頭 $(0.38 \%)$ から検出され，そのすべて から BVDVの NCP 株が分離された（表1，図)。36頭 の内訳は，年齢別に 2 歳齢 22 頭, 3 歳齢 7 頭, 4 歳齢 2 頭, 6 歳齢 2 頭, 7 歳齢 2 頭及び 9 歳齢 1 頭であった. 飼 養農場における用途別では搾乳 21 頭，肉用牛繁殖 2 頭 及び肥育 13 頭であった。品種別ではホルスタイン種 21 頭，黒毛和種 8 頭及び交雑種 7 頭であった。生産農場経 営形態別には酪農 28 頭, 肉用牛繁殖 8 頭であった。そ のうち, 22 頭が導入牛（県内 13 頭，県外 9 頭）であり, 16 頭（73\%）及び6頭（27\%）がそれぞれ酪農場及び 肉用牛繁殖農場において生産された牛であった. BVDV 陽性牛の年齢及び生産農場経営形態の各区分には，統計 学的な有意差が認められた（表 2 ). すなわち，年齢別の 検出率は，死亡時に 2 歳齢であった牛 1,279 頭中 22 頭 $(1.72 \%)$ に対し，3 歳齢以上では 8,083 頭中 14 頭 $(0.17 \%)$ に留まった $(P<0.001)$.これは 2 歳齢の群 から肥育牛 (3 歳齢までに出荷) を除いた場合 $(0.97 \%)$ でも同様であった $(P<0.001)$. 生産農場経営形態別で は酪農が 1,417 戸中 25 戸（1.76\%）と高い值を示し， 肉用牛繁殖の 1,337 戸中 8 戸 $(0.60 \%)$ との間に有意差 がみられた $(P<0.01)$.

分離株の性状解析：分離された 36 株（DC1～DC36） はすべて非細胞病原性（NCP）株であった。また，分子 系統解析より，各ウイルスは遺伝子型 $1 \mathrm{a}$ (5 株)，1b (20 株)，1c（3株）及び $2 \mathrm{a}$ (8 株）に分類された（図). これら分離株と既報 [12］の33株の各遺伝子型の割合 は，それぞれ 1 型が $77.8 \% ， 87.9 \%$ 及び 2 型が $22.2 \%$, $12.1 \%$ あ゙あた．分離された 2 型BVDV 8 株の塩基配列 は，互いに100\%の相同性を示した既報 [12］の 2 型 BVDV 4 株のそれとはすべて異なっていた。 今回分離さ れた 2 型BVDV 8 株中 3 株は県外導入牛から検出され た。

\section{考察}

2 歳齢以上の死亡牛を対象とした本調査では 9,362 頭 中 36 頭 $(0.38 \%)$ の延䯣から BVDV 遺伝子が検出さ れ，そのすべてから $\mathrm{NCP}$ 株が分離された．生前の材料 が得られないため確定診断は不可能だが，PI牛の脳組 織からはBVDV抗原が検出される [14-16] のに対し， 急性感染させた牛の脳組織からは検出されなかったこと が報告されている $[17,18]$ ことから，本調査で陽性と なった 36 頭の牛はすべてPI牛であった可能性が高いと 考えられる。一定の牛群に占める PI 牛の割合は数力国 で報告されており，デンマークのと畜場搬入牛 1,332 頭
のランダム調査（成牛）では $0.9 \%$ [19]，デンマーク， アメリカ及びカナダの牛群（子牛/成牛）では $0.1 \%$ 未 満〜 $1.1 \%$ [20-22］等である。本調査における死亡牛 の BVDV 検出率は $0.38 \%$ あることから，調査対象集 団が異なるものの海外の報告と同程度の割合でPI 牛が 県内に存在する可能性が高いことが明らかとなった。し かしながら, PI 牛の多くは 2 歳齢までに死亡又は淘汰さ れるとされており [1,4-7], Houeら [20］は1歳齢未 満及びそれ以上の年齢区分においてそれぞれ $2.9 \%$ 及び $0.6 \%$ PI 牛が存在していたことを明らかにしている. 本調査においても 2 歳歯の牛（肥育牛を除く）及び 3 歳 齢以上の牛における BVDV 検出率はそれぞれ $0.97 \%$ 及 び $0.17 \%$ ，若い牛が有意に高い結果となった。これ らのデータは本調査の対象とならない2 歳齢未満の牛 に，より高い割合でPI 牛が存在することを示唆してお り, 県内には本調査の検出率 $(0.38 \%)$ 以上のPI 牛が 存在すると推察される.

一方で，無症状のまま泌乳開始年齢にまで成長する個 体も存在することが報告されている $[23,24]$. 本調査 においても 6 歳齢， 7 歳齢及び 9 歳齢の計 5 頭の牛が陽 性を示した。これらの高齢な個体は，県内で出生後，県 外への移動はないことから，多数のPI 産子を分婏する とともに周囲の牛への主要な感染源となっていたと考え られ，県内農場において BVDVをまん延させる要因の 一つになっていたことを示唆している.

生産農場の BVDV 検出率を経営形態ごとに比較する と, 肉用牛繁殖農場に比べ酪農場が有意に高い結果とな った。この背景には酪農場におけるBVDVワクチンの 利用率が低いことがあると考えられる。また，本調査に おける陽性個体の $61 \%$ が導入牛であり，これらの牛は 肉用牛繁殖農場間よりも酪農場間の移動が多かった。牛 群間の BVDV 伝播にはPI 牛あるいはPI胎子を有する妊 娠牛の感受性群への導入が重要な役割を果たすことから $[5,8]$ ，県内において PI 牛が BVDV 感受性個体の多い 酪農場へ移動することにより，新たな PI 牛が発生して いる状況が示唆される。以上から本病の対策として，特 に酪農場における予防対策及び移動の監視強化が必要と 考えられる。

今回分離された 36 株の遺伝子型は $1 \mathrm{a} ， 1 \mathrm{~b} ， 1 \mathrm{c}$ 及び $2 \mathrm{a}$ に分類された。特に 2 型BVDVでは遺伝的に異なる 複数のウイルス株が県内に浸潤しており，過去に分離さ れた系統 [12］とも異なっていたことから，県外から侵 入した可能性も示唆された。本調査における 2 型 BVDV の割合は $22.2 \%$ ありり，北海道を中心とする国内分離 株の $16.6 \%$ [25］及び県内分離株の $12.1 \%$ [12］とす る既報より高率であった，本県における 2 型BVDVの分 布は限局的であると考えられていた [12]ことから，2 型BVDV を含むワクチンが十分に活用されていない. 
今後の本病の対策には，同ワクチンの活用を推奨する必 要がある。

牛群内における PI 牛のスクリーニングには，バルク 乳を用いた検査 $[24,26]$ 及び育成牛群の抽出検査（ス ポット法）［27-29］などの方法の有効性が報告されて いるが，PI牛が摘発された際の対応の問題から大規模 な実施は難しい。 今回行った BVDV 検査法は，対象が2 歳齢以上の死亡牛に限られるものの，約 2 年の期間内に 県内の約 9 割の酪農場から材料が得られたことから，広 い範囲の感染状況及び疫学的特徵の把握に有用であるこ とが確認された。これら情報を基に高リスク群に対する 重点的なスクリーニングを行うことで，より効率的にPI 牛を摘発できると考えられる，BSE 検査終了後は検体 の収集が困難になると考えられるため，検査が継続され る期間内に感染率及びウイルス等の疫学的情報の収集を 行う必要がある。本手法が国内における BVD 清浄化対 策の一助となることを期待する。

\section{引 用 文 献}

[1] Baker JC : Bovine viral diarrhea virus: A review, J Am Vet Med Assoc, 190, 1449-1458 (1987)

[2] McClurkin AW, Littledike ET, Cutlip RC, Frank GH, Coria MF, Bolin SR : Production of cattle immunotolerant to bovine viral diarrhea virus, Can J Comp Med, 48, 156-161 (1984)

[3 ] 田島誉士 : 牛ウイルス性下痢ウイルス感染症, 日獣会誌, 65, 111-117 (2012)

[4 ] Houe $\mathrm{H}$ : Epidemiology of bovine viral diarrhea virus, Vet Clin North Am Food Anim Pract, 11, 521-548 (1995)

[5] Duffell SJ, Harkness JW : Bovine virus diarrheamucosal disease infection in cattle, Vet Rec, 117, 240-245 (1985)

[6 ] Houe H : Suvivorship of animals persistently infected with bovine virus diarrhea virus (BVDV), Prev Vet Med, 15, 275-283 (1995)

[ 7 ] Baker JC : The clinical manifestations of bovine viral diarrhea infection, Vet Clin North Am Food Anim Prac, 11, 425-445 (1995)

[8] Houe H : Epidemiological features and economical importance of bovine virus diarrhoea virus (BVDV) infections, Vet Microbiol, 64, 89-107 (1999)

[9] Vilcek S, Herring AJ, Herring JA, Nettleton PF, Lowings JP, Paton DJ : Pestiviruses isolated from pigs, cattle and sheep can be allocated into at least three genogroups using polymerase chain reaction and restriction endonuclease analysis, Arch Virol, 136, 309-323 (1994)

[10] Saino H, Watanabe H, Ikehata T : Immunoperoxidase procedures for rapid detection of bovine viral diarrhea-mucosal disease virus antigen, J Vet Med Sci, 56, 805-807 (1994)

[11] Tamura K, Dudley J, Nei M, Kumar S : MEGA4: Molecular evolutionary genetics analysis (MEGA) soft- ware version 4.0, Mol Biol Evol, 24, 1596-1599 (2007)

［12］八重樫岳司，清宮幸男，迫田義博，関 慶久：岩手県で 分離された牛ウイルス性下痢ウイルスの分子系統解析， 日獣会誌，57，31-35（2004）

[13] Saitou N, Nei M : The neighbor-joining method: A new method for reconstructing phylogenetic trees, Mol Biol Evol, 4, 406-425 (1987)

[14] Bielefeldt Ohmann $\mathrm{H}: \mathrm{BVD}$ virus antigens in tissues of persistently viremic, clinically normal cattle: Implication for the pathogenesis of clinically fatal disease, Acta Vet Scand, 29, 77-84 (1988)

[15] Fernandez A, Hewicker M, Trautwein G, Pohlenz J, Liess B : Viral antigen distribution in the central nervous system of cattle persistently infected with bovine viral diarrhea virus, Vet Pathol, 26, 26-32 (1989)

[16] Hewicker M, Wohrmann T, Fernandez A, Trautwein G, Liess B, Moennig V : Immunohistological detection of bovine viral diarrhoea virus antigen in the central nervous system of persistently infected cattle using monoclonal antibodies, Vet Microbiol, 23, 203-210 (1990)

[17] Liebler-Tenorio EM, Ridpath JF, Neill JD : Distribution of viral antigen and development of lesions after experimental infection of calves with a BVDV 2 strain of low virulence, J Vet Diagn Invest, 15, 221-232 (2003)

[18] Liebler-Tenorio EM, Ridpath JE, Neill JD : Distribution of viral antigen and tissue lesions in persistent and acute infection with the homologous strain of noncytopathic bovine viral diarrhea virus, J Vet Diagn Invest, 16, 388-396 (2004)

[19] Meyling A : Detection of BVD virus in viremic cattle by an indirect immunoperoxidase technique, Recent Advances in Virus Diagnosis, McNulty MS, et al eds, 37-46, Martinus Nijhoff Publishers, Boston (1984)

[20] Houe H, Meyling A : Prevalence of bovine virus diarrhea (BVD) in 19 Danish dairy herds and estimation of incidence of infection in early pregnancy, Prev Vet Med, 11, 9-16 (1991)

[21] Houe H, Baker JC, Maes RK, Wuryastuti H, Wasito R, Ruegg PL, Lloyd JW : Prevalence of cattle persistently infected with bovine viral diarrhea virus in 20 dairy herds in two counties in central Michigan and comparison of prevalence of antibody-positive cattle among herds with different infection and vaccination status, J Vet Diagn Invest, 7, 321-326 (1995)

[22] Taylor LF, Van Donkersgoed J, Dubovi EJ, Harland RJ, van den Hurk JV, Ribble CS, Janzen ED : The prevalence of bovine viral diarrhea virus infection in a population of feedlot calves in western Canada, Can J Vet Res, 59, 87-93 (1995)

［23］ 小佐々隆志，田島誉士，大橋和彦，小沼 操：臨床症状 を指標とした牛ウイルス性下痢ウイルスの污染状況調 査，日獣会誌，57，511-514（2004）

[24] Kozasa T, Tajima T, Yasutomi I, Sano K, Ohashi K, Onuma M : Relationship of bovine viral diarrhea virus persistent infection to incidence of diseases on 
dairy farms based on bulk tank milk test by RT-PCR, Vet Microbiol, 106, 41-47 (2005)

[25] Matsuno K, Sakoda Y, Kameyama K, Tamai K, Ito A, Kida $\mathrm{H}$ : Genetic and pathobiological characterization of bovine viral diarrhea viruses recently isolated from cattle in Japan, J Vet Med Sci, 69, 515-520 (2007)

[26] Radwan GS, Brock KV, Hogan JS, Smith KL : Development of a PCR amplification assay as a screening test using bulk milk samples for identifying dairy herds infected with bovine viral diarrhea virus, Vet Microbiol, 44, 77-91 (1995)

[27] Houe H, Baker JC, Maes RK, Ruegg PL, Lloyd JW : Application of antibody titers against bovine viral diarrhea virus (BVDV) as a measure to detect herds with cattle persistently infected with BVDV, J Vet Diagn Invest, 7, 327-332 (1995)

[28] Seki Y, Seimiya YM, Yaegashi G, Sato C : Identification of herds with cattle persistently infected with bovine viral diarrhea virus by virological evaluation of three calves, J Vet Med Sci, 68, 255-258 (2006)

[29] Seki Y, Seimiya YM, Motokawa M, Miyazaki H, Konno M, Yaegashi G : Field application of the combination of neutralizing test and virus isolation, socalled spot test, to detect herds including cattle persistently infected with bovine viral diarrhea virus, J Vet Med Sci, 69, 1087-1089 (2007)

\title{
Surveillance of Bovine Viral Diarrhea Virus Infection in Dead Cattle in Iwate Prefecture
}

\author{
Kazuhiro FUKUNARI ${ }^{1 \dagger}$, Gakuji YAEGASHI ${ }^{1)}$, Shin CHIBA $^{1)}$ and Kenichiro KAMEYAMA ${ }^{2)}$ \\ 1) Iwate Prefecture Central Livestock Hygiene Service Center, 390-5 Sunagome, Takizawa- \\ mura, Iwategun, 020-0173, Japan \\ 2) National Institute of Animal Health, 3-1-5 Kannondai, Tsukuba-shi, 305-0856, Japan
}

\section{SUMMARY}

During the 25 months from March 2011 to March 2013, a total of 9,362 medulla oblongata samples collected from dead adult cattle (two years or older) and used for bovine spongiform encephalopathy (BSE) surveillance at 2,203 farms in Iwate Prefecture, Japan. The samples were utilized to investigate the prevalence of bovine viral diarrhea (BVD) in the area. BVD viruses (BVDVs) were detected from 36 cattle (0.38\%) on 31 farms (1.41\%). A significant difference was observed in each BVDV detection rate of 22 cattle (1.72\%) that were two years old at death and 25 dairy farms (1.76\%). In comparison to the results of this research, the percentage of genotype 2 in isolated viruses was high (22.2\%). These results suggest that monitoring the infection in dairy cattle and the spread of genotype 2 viruses is important for eradication of BVDV in Iwate. It was also concluded that medulla oblongata samples obtained from dead cattle are useful for efficiently investigating BVDV prevalence and epidemiology.

- Key words : Bovine viral diarrhea virus, dead cow, epidemiology, genotype, medulla oblongata.

$\dagger$ Correspondence to : Kazuhiro FUKUNARI (Iwate Prefecture Central Livestock Hygiene Service Center) 390-5 Sunagome, Takizawa-mura, Iwategun, 020-0173, Japan

TEL 019-688-4111 FAX019-688-4012 E-mail:k-fukunari@pref.iwate.jp J. Jpn. Vet. Med. Assoc., 66, $785 \sim 790$ (2013) 